\title{
Tectonic Influence on Speleogenesis of Sea Caves on Biševo Island (UNESCO Global Geopark Vis Archipelago, Adriatic Sea, Croatia)
}

\author{
Ivan Mišur *, Marko Budić, Tomislav Kurečić and Tvrtko Korbar (D) \\ Croatian Geological Survey, Milana Sachsa 2, 10000 Zagreb, Croatia; mbudic@hgi-cgs.hr (M.B.); \\ tkurecic@hgi-cgs.hr (T.K.); tkorbar@hgi-cgs.hr (T.K.) \\ * Correspondence: imisur@hgi-cgs.hr
}

check for

updates

Citation: Mišur, I.; Budić, M.; Kurečić, T.; Korbar, T. Tectonic Influence on Speleogenesis of Sea Caves on Biševo Island (UNESCO Global Geopark Vis Archipelago, Adriatic Sea, Croatia). Geosciences 2021, 11, 341. https://doi.org/ 10.3390/geosciences11080341

Academic Editors: Karoly Nemeth and Jesus Martinez-Frias

Received: 11 June 2021

Accepted: 29 July 2021

Published: 13 August 2021

Publisher's Note: MDPI stays neutral with regard to jurisdictional claims in published maps and institutional affiliations.

Copyright: (c) 2021 by the authors. Licensee MDPI, Basel, Switzerland. This article is an open access article distributed under the terms and conditions of the Creative Commons Attribution (CC BY) license (https:/ / creativecommons.org/licenses/by/ $4.0 /)$.

\begin{abstract}
A geological and speleological investigation was conducted in the famous Blue Cave (Modra špilja) and the Monk Seal Cave (Medvidina špilja) on Biševo Island (Croatia) to promote the island's geoheritage through the new Visitor Centre. The island is mainly composed of Cretaceous to Paleogene neritic carbonates, which form the bedrock, whereas parts of the island are covered with thin Quaternary sediments. The caves are of small dimensions and a simple layout, composed of the main channel and few shorter side channels, all positioned in the tidal zone. Thus, the caves are semisubmerged sea caves located along the coastline. The Blue Cave and the Monk Seal Cave developed within the bedrock limestones and dolostones, respectively, within a zone of left-lateral NNE-SSW striking strike-slip faults that belong to the Biševo fault system. Conjugated discontinuities within the carbonate bedrock indicate a specific strike-slip tectonic regime. Additionally, the host rocks were probably also deformed and fractured during the rise of salt diapirs that characterise this part of the Adriatic foreland. Tectonic and bedding discontinuities form the fragments of the host rock, that combined with the impacts of the strong southern waves, significantly influenced the genesis of the caves.
\end{abstract}

Keywords: speleogenesis; Biševo Island; UNESCO Global Geopark Vis Archipelago; Blue Cave; Monk Seal Cave

\section{Introduction}

The island of Biševo is part of the Vis Archipelago situated in the central Adriatic Sea (Dalmatia, Croatia), comprising a few remote open-sea islands and numerous islets and rocks (Figure 1). According to the population census from 2011, the island of Vis had 3504 inhabitants, and it is the remotest populated island in Croatia. The whole archipelago was recognised as a potential geopark in 2016 [1] and declared by UNESCO as a Global Geopark in 2019 (https:/ / geopark-vis.com/en/, accessed on 26 July 2021.). The archipelago deserves the status, because, in this relatively small maritime area $\left(6661 \mathrm{~km}^{2}\right)$ that comprises a few small islands, islets, and rocks (the land area is approximately $100 \mathrm{~km}^{2}$ ), there are five geological and geomorphological monuments of nature, two significant landscapes (Table 1), 70 recognised geosites, and many other natural beauties that should be offered to visitors in a sustainable organised way defined by the concept of UNESCO Global Geoparks.

The beautiful natural phenomena and landscapes in the central Adriatic archipelago mostly owe their existence to geological structures and geomorphological processes. Furthermore, the largest island of Vis has its own (local) but limited freshwater supply entirely predisposed by the specific geology. That is why the archipelago deserves the highest level of protection and promotion as an extraordinary place on Earth-a feature that can be used for world-class sustainable tourism. A geopark status allows both the conservation of geological heritage and the promotion of geotourism, which attracts mainly environmentfriendly tourists. The UNESCO Geopark status for such a distant archipelago is an excellent 
opportunity for inhabitants to organise sustainable development and validate natural phenomena (e.g., Puerto-Princesa Subterranean River National Park, Philippines; Belitong UNESCO Global Geopark, Indonesia; Hong Kong UNESCO Global Geopark).

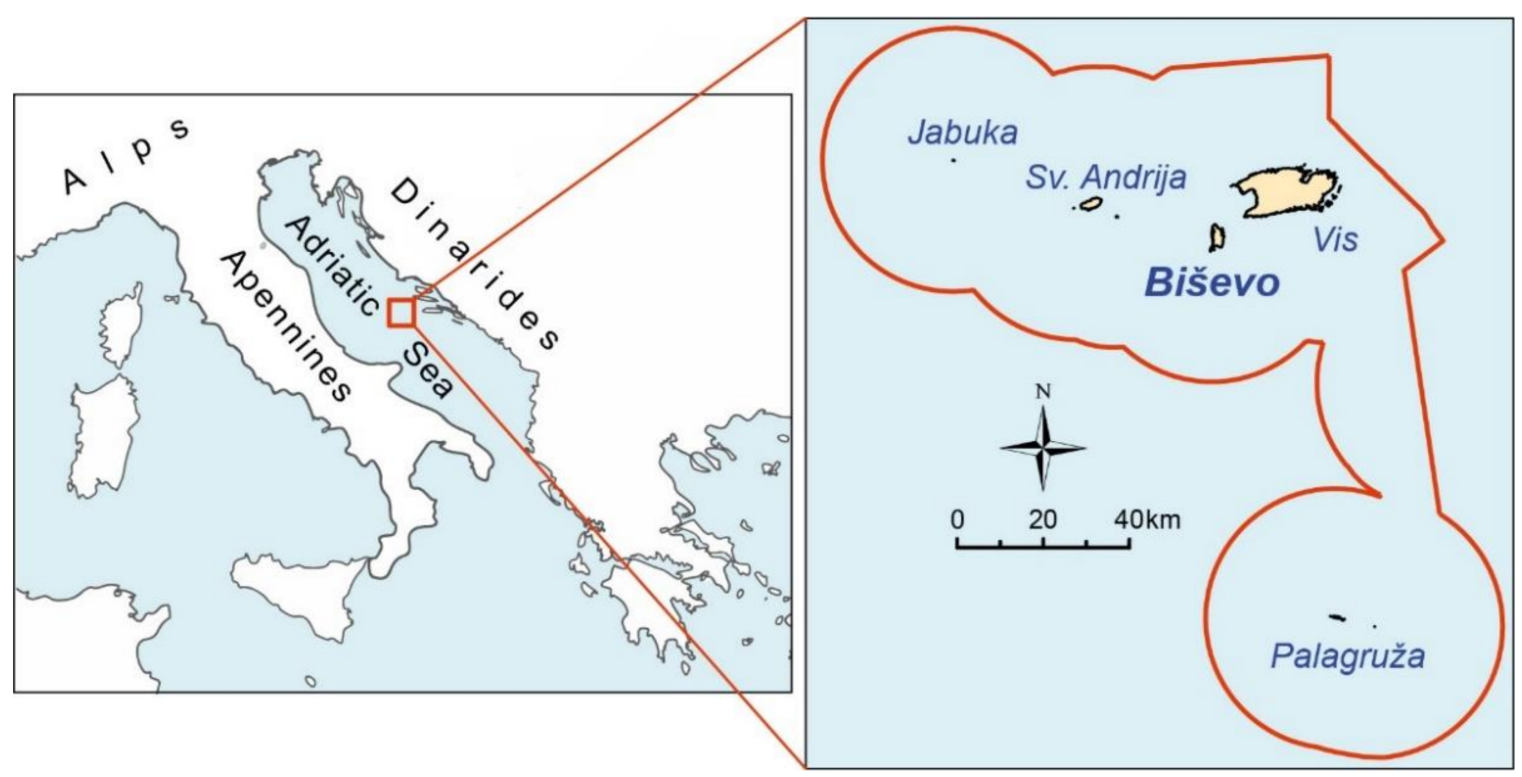

Figure 1. Map with the location of the Adriatic Sea (on the left), along with the UNESCO Geopark Vis Archipelago area outlined in red (on the right), showing the position of Biševo Island.

Table 1. List of protected geosites in the Vis Archipelago.

\begin{tabular}{lll}
\hline & Locality & Protection Status \\
\hline 1 & The Blue Cave & geomorphological monument of nature \\
2 & The Monk Seal Cave & geomorphological monument of nature \\
3 & Jabuka islet & geological monument of nature \\
4 & The Green Cave on the islet of Ravnik & geomorphological monument of nature \\
5 & Brusnik & geological monument of nature \\
6 & Stiniva Bay & significant landscape \\
7 & Ravnik & significant landscape \\
\hline
\end{tabular}

The island of Biševo has a long-standing tradition of tourist visitation of attractive geological sites. In 1884, Baron Eugen von Ransonnet-Villez, a painter from Vienna, discovered a natural geomorphological luminous phenomenon on the island-the Blue Grotto (the Blue Cave in English; Modra špilja in Croatian). After an article was published in a Viennese newspaper, where Rannsonet-Villez described his discovery, the first organised tourist visit to this newly discovered natural wonder was arranged. This article, published 132 years ago, marked the beginning of tourism in the area. The Blue Cave is famous for its blue light effect, which occurs when the morning sunlight enters the cave through its submerged eastern entrance and reflects from the white sandy bottom creating a unique visual ambience [2].

Another famous cave on the island of Biševo is the Monk Seal Cave (Medvidina špilja, in Croatian), named after a rare seal species (Monachus monachus) that was discovered breeding on the small beach at the end of the cave. With the length of the channel polygons being over $160 \mathrm{~m}$, it is the longest cave on the island and among the longest described sea caves in the Adriatic.

The two caves are the most famous geomorphological attractions on the island of Biševo and are formally protected as geomorphological monuments of nature (http: / / moreikrs.hr/spomenik-prirode, accessed on 26 July 2021.). The caves are developed 
within the bedrock of the island, which is composed of Cretaceous and Paleogene carbonates [3] (Figure 2).
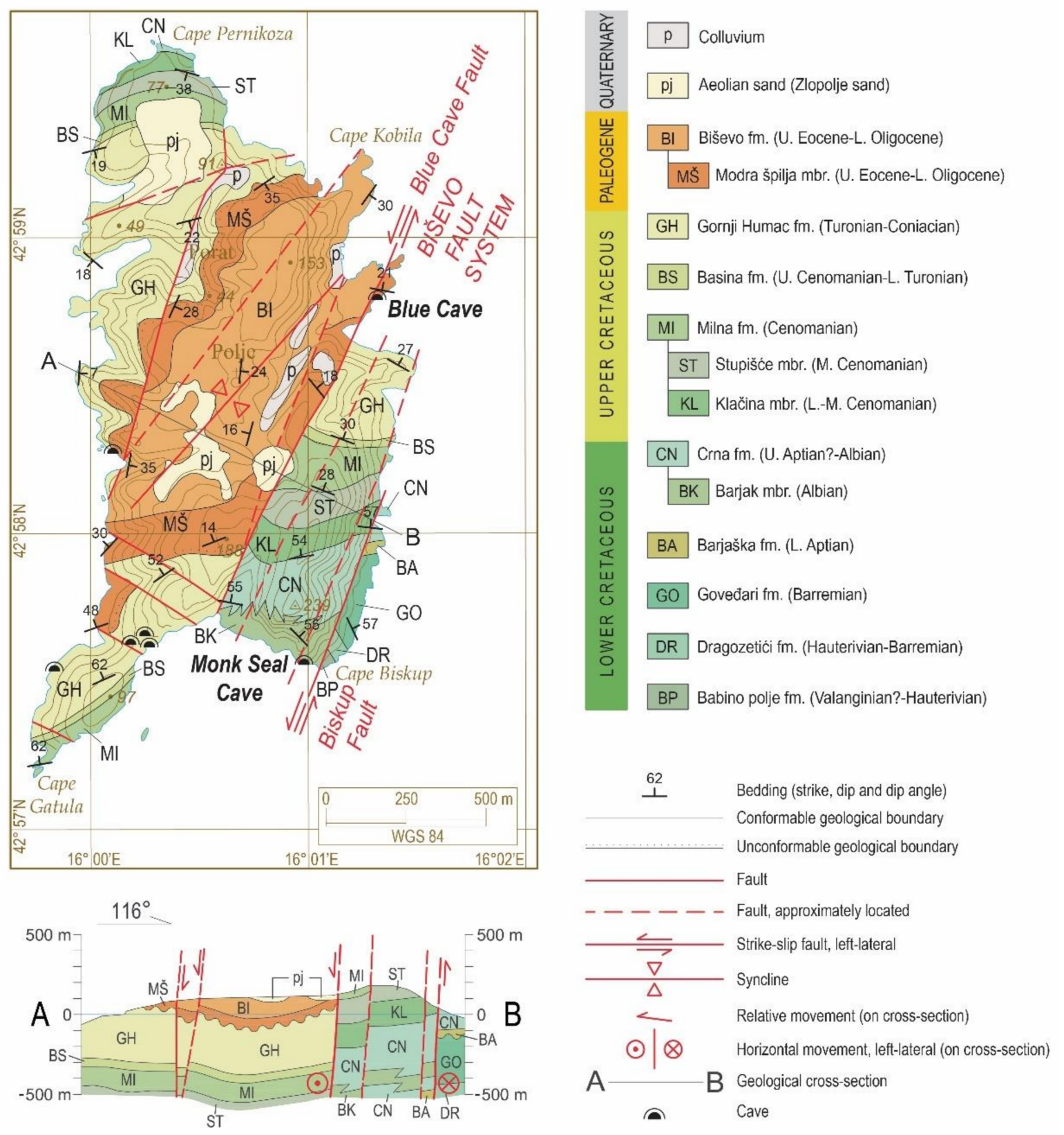

Figure 2. Geological map and the (A,B) cross-section (including legend) of Biševo Island [3], showing positions of all investigated speleological objects and the two most popular caves presented in this paper.

During the latest geological and speleological research in 2019, to promote geological and geomorphological heritage in the new Visitor Centre, seven speleological objects were mapped. Two, i.e., the largest and the most famous, are presented in this paper. The geometry and geological structure of the two most popular sea caves in the Adriatic are described here for the first time in a scientific paper. The exploration resulted in a comprehensive picture of the cave origin, closely related to specific geological and tectonic features. 


\section{Geographical and Geological Setting}

Situated in the central Adriatic Sea (Figure $1 ; 42.97928^{\circ} \mathrm{N}, 16.01109^{\circ} \mathrm{E}$ ), Biševo belongs to the group of the remotest inhabited islands of Croatia (with just a few permanent inhabitants). The surface area of the island is $5.8 \mathrm{~km}^{2}$. Biševo Island is at a relatively low altitude, with the highest peak, Stražbenica, situated on the SE part of the island at $239 \mathrm{~m}$ a.s.l. The morphology of the island is characterised by generally steep and rocky shores and high coastal cliffs, and the altitude decreases towards the western coast. The eastern, southern, and western slopes of the island are dissected with gullies and dry valleys. This area has the climate type Csa (Mediterranean climate with a hot summer) [4]. The climatological characteristics of the area are visible from the data of the local Biševo meteorological station (a precipitation station on Biševo) and the stations on the surrounding islands, observed in the period 1958-2018 [5]. The mean average annual air temperature on the surrounding islands ranges from $15.80-16.71^{\circ} \mathrm{C}$, and the mean total annual precipitation on Biševo is $617 \mathrm{~mm}$.

The present-day peri-Adriatic area belongs to a major regional lithospheric unit of African affinity - the Adriatic microplate or Adria [6]. Following the breakup of Pangea in the middle Triassic [7-9], a long-lasting Adriatic carbonate platform was formed [10] and persisted into the Palaeogene [11]. Although the neritic environments existed during the Late Cretaceous to Palaeogene in the present-day island of Biševo (central Adriatic), the contemporaneous pelagic environments characterised the surrounding areas, thus forming a complex system of subtropical islands and embayments [12,13].

Tectonically, the islands of Biševo belong to the Adriatic foreland that is not involved in the Dinaridic thrust-related deformations but is affected predominantly by wrench and salt tectonics that characterise the central Adriatic area [11,14,15]. Inferred deeprooted lineaments, originated during the Triassic breakup of Pangea, probably affected pre-orogenic sedimentation of a locally thick late Triassic volcanic-sedimentary-evaporitic successions $[7,14]$ and later neritic and pelagic carbonates [10]. These lineaments were reactivated during Cenozoic orogenic deformations [11] in the common foreland of the older Dinarides on the NE and the younger Apennines on the SW. The GPS data imply that the Adria is moving continually northward [16] and is divided into the two segments delimited around the central Adriatic area [11,17]. Thus, the central Adriatic area is seismically active [18], and salt tectonics probably contribute to the wrench tectonics [11,12,14]. Miocene onset of the diapirism is recognised on shallow seismic images [15] and in the stratigraphy of the redeposited sediments around the salt peaks [19]. Related deformations continue to date, implying that the present-day geomorphology and bathymetry of the central Adriatic is probably an expression of the specific active tectonics.

The oldest rocks exposed on the island of Biševo are Lower Cretaceous dolomites of the Babino Polje formation (BP) (Figure 2). The rest of the $>1300 \mathrm{~m}$ thick succession of Cretaceous carbonates is characterised predominantly by various lithotypes of shallowwater limestones. The top of the Upper Cretaceous limestones (Turonian-Coniacian) is paleo-karstified and unconformably overlain by the Late Eocene to early Oligocene skeletal limestones: the older Modra špilja formation (MŠ on Figure 2) and the younger Biševo formation (BI on Figure 2). Thick-bedded skeletal limestones characterise the former, with many clayey horizons in the lower part. In contrast, the latter is characterised by poorly cemented nodular bioclastic limestones deposited on the distal Dinaric foreland ramp. The bedrock is partly covered by Quaternary colluvium—rockfall and slope breccia [3]. The aeolian sands were deposited during the last glacial maximum, when the sea level was up to $120 \mathrm{~m}$ lower and the island was a hill surrounded by a broad steppe [20].

Specific coastal geomorphological features such as tidal notches are not observed. However, submerged notches can be masked by thick recent biogenic constructions and encrustations that extensively grow at the mean sea level [21].

The island is intersected with numerous faults and fractures, mostly related to the NNE-SSW striking strike-slip Biševo fault system and the conjugated faults and fractures [3]. The tectonic lineaments, in combination with lithology, highly influenced devel- 
opment of the geomorphology of the island. The prominent valley in the central part of the island strikes along the main fault zone (Blue Cave fault) and the outcrops of rocks that are more prone to weathering (e.g., Biševo fm.). At the same time, the ridges are composed of fully cemented and less tectonised carbonates. The tectonic features are probably associated also with a complex salt diapir that is supposedly in the subsurface of the island [15] but is still underexplored.

\section{Materials and Methods}

Information about the speleological objects on Biševo Island was gathered from the literature, inhabitants, and the Geopark Vis Archipelago team. Field research included field prospection of the island and measuring of all discovered speleological objects.

Lithological units and structural features at the island and within caves were recognised following the basic geological map at the scale of 1:50,000 [3] (Figure 2). Field determination of the lithology was conducted with a hand lens and compared to the existing data.

The structural features were measured within the caves and at the surface (Tables 2 and 3). Structural measurements on the field were conducted with a Brunton Pocket Transit compass. Measurements included orientation of the bedding planes, fractures, and faults (dip direction/dip angle). Data of measured planes are presented as dip direction (azimuth) and dip angle. Slickenside striations are presented as the angle between the observed linear element (striation) on a fault plane and the horizontal strike of the same plane.

Table 2. Tectonic and depositional discontinuities measured at the surface of Biševo Island, in the close vicinity of the two caves.

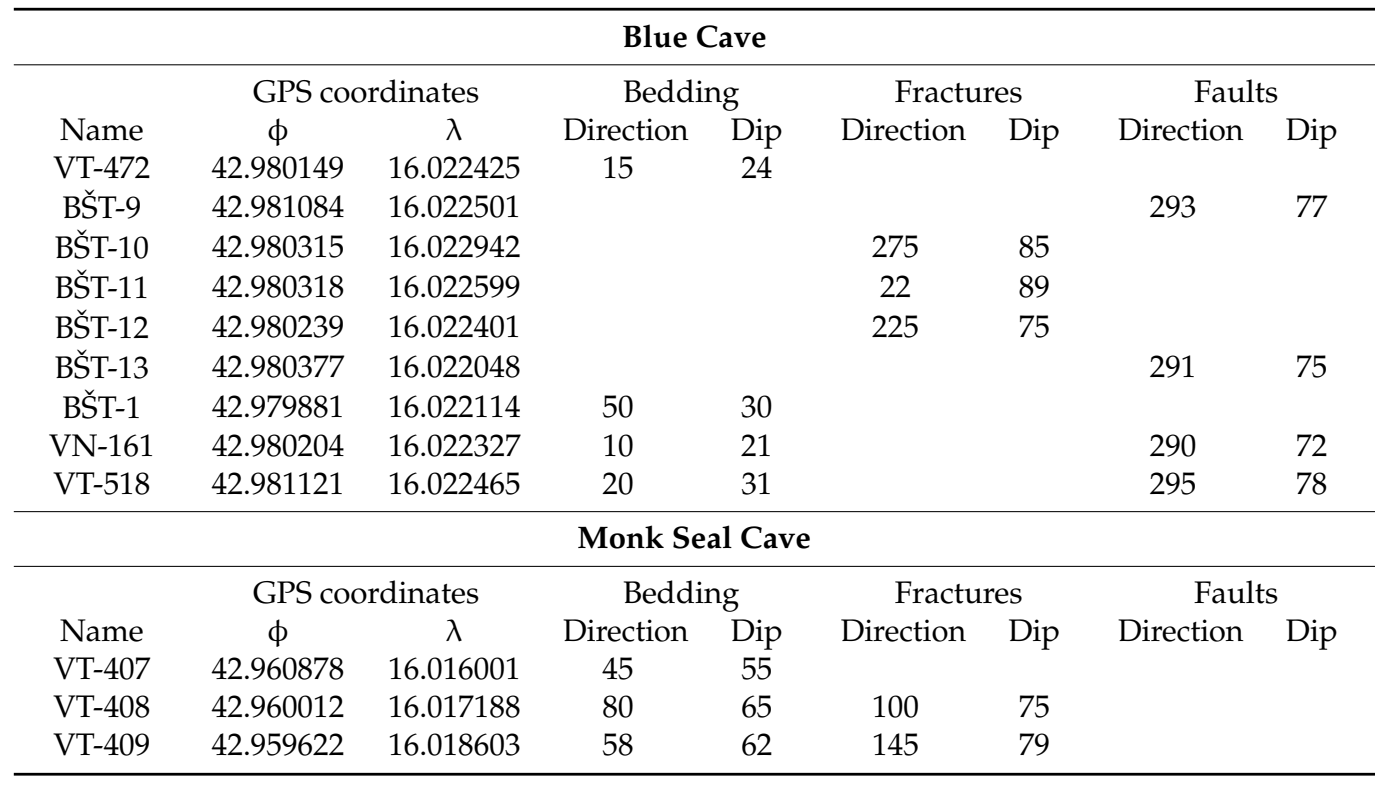

Caves were mapped using a combination of digital and classical survey methods by the International Union of Speleology (UIS) standard (UIS-5-4-BC grade [22]). Classical methods were used for submerged parts of the caves and digital methods were used for dry parts. Measuring tape and a Suunto Tandem (compass and inclinometer) were used for distance, depth, azimuth, and inclination measurements in the submerged parts of the caves. All underwater observations, measurements, and mapping were performed by diving. 
Table 3. Tectonic and depositional discontinuities measured inside of the Blue Cave and Monk Seal Cave.

\begin{tabular}{|c|c|c|c|c|c|c|c|}
\hline \multicolumn{8}{|c|}{ Blue Cave } \\
\hline & GPS coordinates & \multicolumn{2}{|c|}{ Bedding } & \multicolumn{2}{|c|}{ Fractures } & \multicolumn{2}{|c|}{ Faults } \\
\hline Name & $\phi \quad \lambda$ & Direction & Dip & Direction & Dip & Direction & Dip \\
\hline MŠ-0 & & & & & & 290 & 70 \\
\hline MŠ-2 & & 350 & 23 & & & 270 & 80 \\
\hline MŠ-4 & & & & & & 275 & 85 \\
\hline MŠ-5 & & & & & & 285 & 85 \\
\hline MŠ-5/1 & & & & 40 & 65 & & \\
\hline MŠ-10 & & & & 225 & 65 & & \\
\hline \multicolumn{8}{|c|}{ Monk Seal Cave } \\
\hline & GPS coordinates & \multicolumn{2}{|c|}{ Bedding } & \multicolumn{2}{|c|}{ Fractures } & \multicolumn{2}{|c|}{ Faults } \\
\hline Name & $\phi \quad \lambda$ & Direction & Dip & Direction & Dip & Direction & Dip \\
\hline ME-0 & & & & 90 & 75 & 20 & 78 \\
\hline ME-0 & & & & & & 105 & 60 \\
\hline ME-2 & & & & & & 5 & 75 \\
\hline ME-3 & & & & 80 & 80 & 5 & 65 \\
\hline ME-4 & & & & & & 20 & 80 \\
\hline ME-5/1 & & & & & & 10 & 68 \\
\hline
\end{tabular}

A tablet equipped with Topodroid 5.0.59 software, paired with a laser distance meter and an electronic clinometer, was used in the dry parts of the caves. Finally, draft maps of dry and submerged channels were merged into final cave maps.

Survey data were processed using Speleoliti 4 software (http:/ / speleoliti.speleo.net/ index-en.html, accessed on 3 October 2019.), and Topodroid 5.0 .59 (https:/ / topodroid. en.aptoide.com/app, accessed on 10 September 2019.), before being finalised using Corel draw $\times 17$ graphical software. Magnetic declination was corrected for $4.05^{\circ} \mathrm{E}$ (for date of measurement 16 September 2019), according to the National Centres for Environmental Information of USA (https: / / www.ngdc.noaa.gov/geomag/declination.shtml, accessed on 3 October 2019).

\section{Results}

\subsection{Structural Measurements on the Surface of Biševo Island around the Caves}

In the vicinity and above the Blue Cave, the host limestone (MŠ, Figure 2) is thickbedded, generally inclined to NNE by an angle of $21^{\circ}$ to $31^{\circ}$. Above the main entrance of the Blue Cave is a distinct Blue Cave fault plane with a general dip direction of WNW and a dip angle of $70^{\circ}$ (Figure 3A). The fault plane borders the cave from the west (Figure 4). In the surroundings of the cave, the fractures measured at the surface (Table 2) are similar in orientation to the Blue Cave fault system and interpreted as the fractures accompanying the major fault. There are visible conjugated fractures on the cliffs above the submerged entrance, measured inside the cave right above the submerged entrance (see further details in Section 4.2, Figures 3B, 4 and 5C,E).

In the vicinity of the Monk Seal Cave, the bedding is inclined to the NE with a dip angle from $55^{\circ}$ to $62^{\circ}$ (Table 2). Contrary to the Blue Cave, fewer structural elements were measured around the Monk Seal Cave because of steep and inaccessible slopes above the cave. There is a fracture system with a dip direction to the SE and a steep dip angle. Two fault planes are visible on the entrance part to the cave (Figures 6 and 7A,B), and, east to the cave, there is a fractured zone of the "Biskup fault", which is a part of the major Biševo left-lateral strike-slip fault system, traversing the whole Biševo Island (Figure 2A) [3]. 


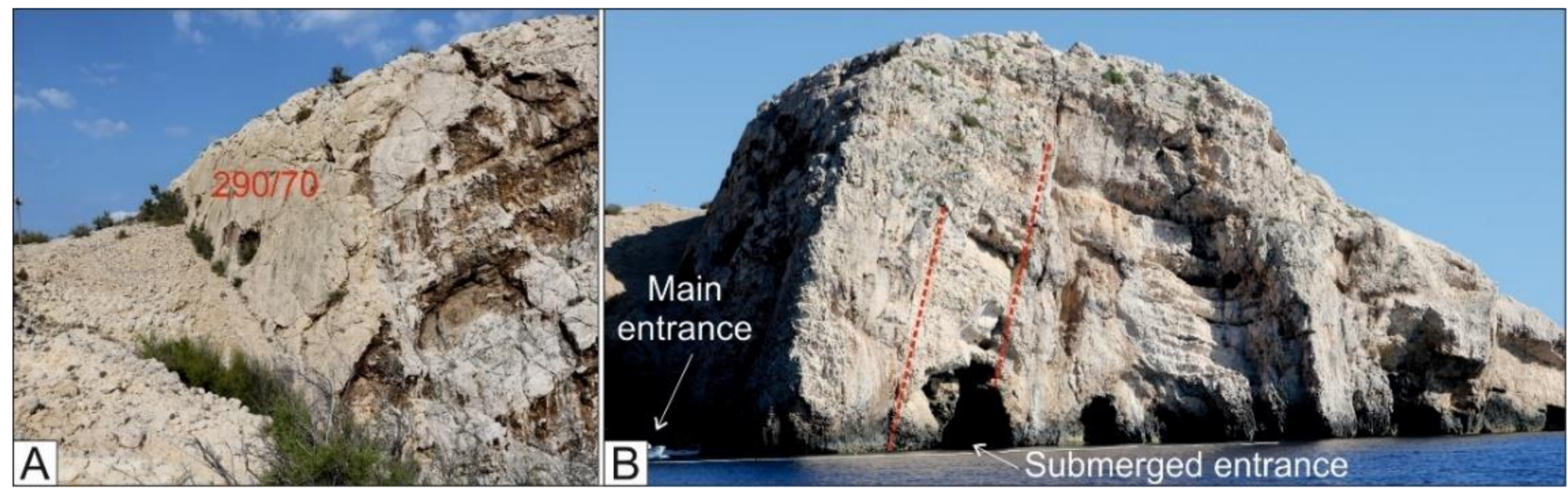

Figure 3. (A) The Blue Cave fault plane above the main entrance to the cave. (B) Vertical cliff on the eastern side of the Blue Cave, host rock, and marked fracture systems (red dashed lines) also measured inside the cave. The cliff is approximately $40 \mathrm{~m}$ high (small boat at the main entrance for the scale).

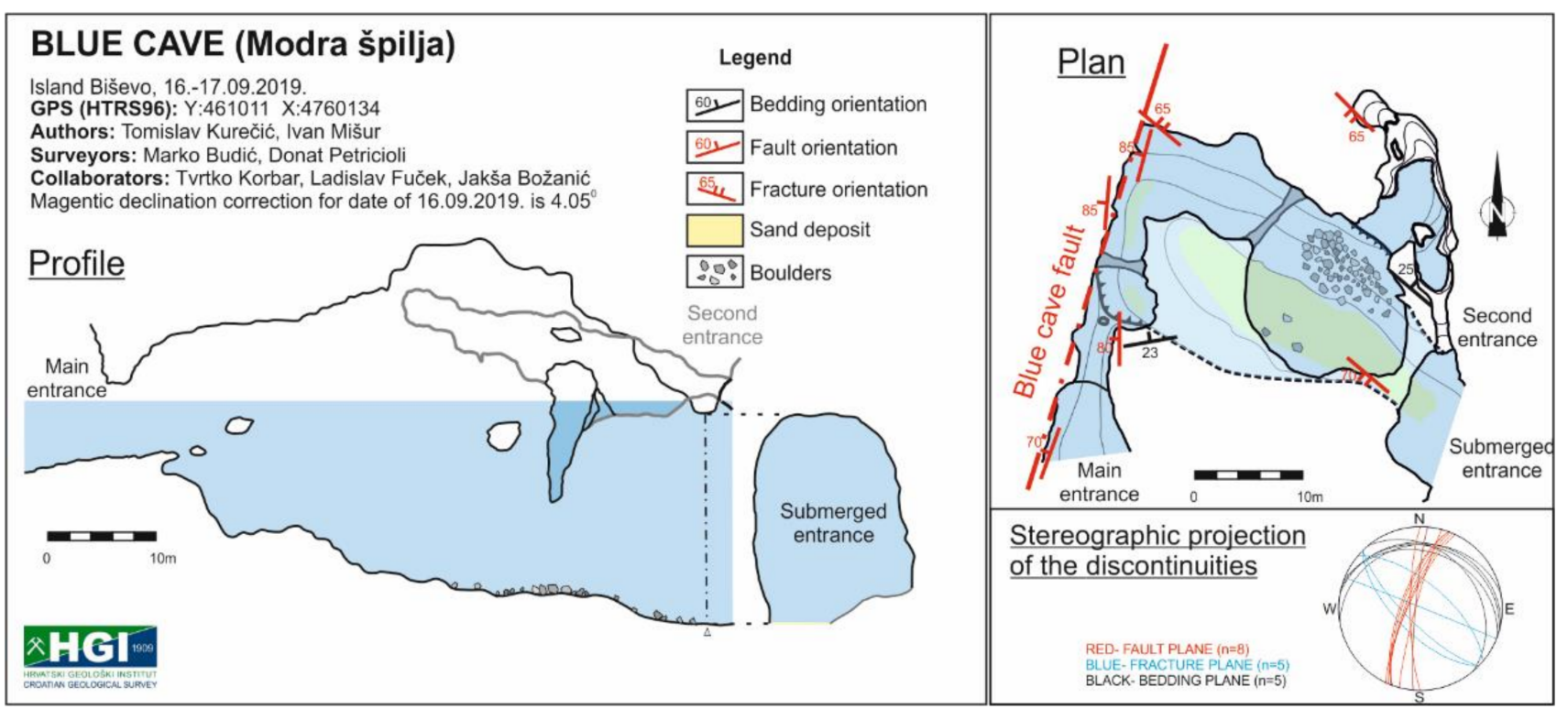

Figure 4. Plan and profile of the Blue Cave (Modra špilja) (cave symbols according to [23,24]), with marked orientations of the fault planes, fractures, and bedding planes. Stereographic projection (bottom right) of all measured discontinuities on the surfaces and in the cave (lower-hemisphere projection).

\subsection{The Blue Cave}

The Blue Cave is $24 \mathrm{~m}$ long with a maximum depth of $20 \mathrm{~m}$ below sea level. The maximal measured elevation of the cave is $35 \mathrm{~m}$ (20 m is submerged, and about $15 \mathrm{~m}$ is above sea level). Due to the complex and inaccessible ceiling of the cave, maximal height is not absolute precise (Figure 4). There are three entrances into the cave, accessible only by sea (Figure 4). Two of them are on the southeastern coast; the most prominent entrance is submerged $(18 \times 13 \mathrm{~m})$ (Figure $5 \mathrm{~A})$, and the second, smaller entrance is above mean sea level $(1.5 \times 1 \mathrm{~m})$ (Figure $5 \mathrm{~B})$. The main entrance is partly submerged and located on the southern coast. The entrance was expanded by explosives in the 19th century; it now measures $2 \times 6 \mathrm{~m}$ and is used for the entrance of smaller boats (Figure 5A). 


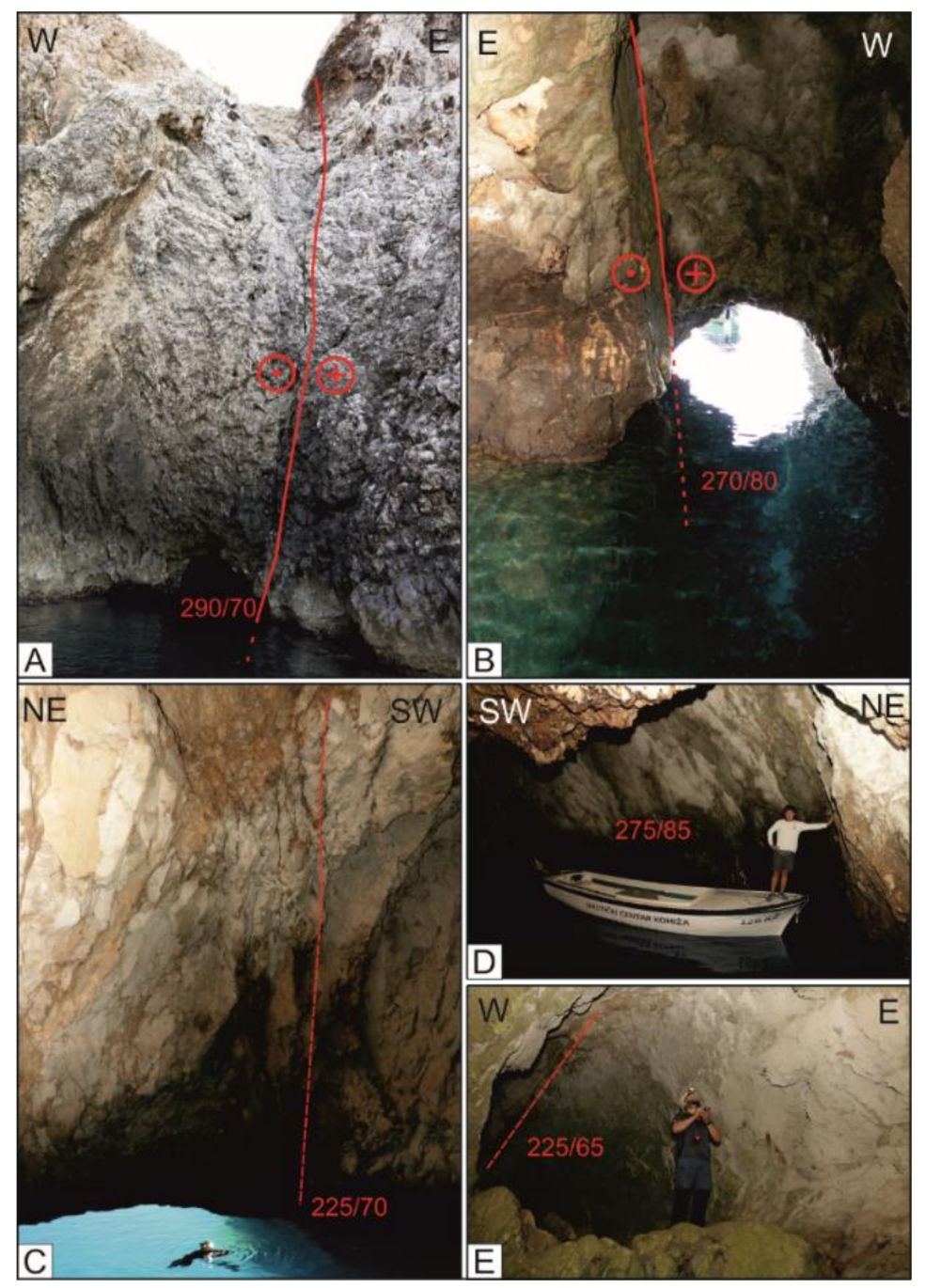

Figure 5. On the photographs of the Blue Cave, structural measurements are marked. The red lines mark fault planes. The dashed lines represent fracture system planes. Dip direction/dip angle is marked by red numbers. (A) The main entrance into the Blue Cave with a marked strike-slip fault (sinistral). (B) The main entrance photo, taken from inside out, with marked fault plane. (C) The submerged entrance and marked fracture system. (D) The fault plane on the southwestern wall of the Blue Cave. (E) Fracture system in a small dry channel on the NE part of the cave.

Rocks hosting the Blue Cave (Modra špilja) are referred to as the homonymous lithological unit (MŠ on Figure 2), described as thick-bedded Palaeogene limestones that are more than $30 \mathrm{~m}$ thick and characterised predominantly by foraminiferal-bioclastic wackestones to rudstones.

Prominent subvertical discontinuities crosscut the Blue Cave channels, as well as its submerged entrance. Four subvertical fault planes, two bedding planes, and three fractures were measured in the cave (Table 3, Figure 5). The fault planes of the Blue Cave fault were measured along the main entrance with a dip direction of $270^{\circ}$ to $290^{\circ}$ and a dip angle of $70^{\circ}$ to $85^{\circ}$ (Figure 5A,B,D). Above the largest, submerged entrance, on the cave walls, two conjugated fractures are visible with general dip directions and dip angles of 40/65 and 225/65 (Figure 5C,E). The fracture system crosscuts the cave almost perpendicularly to the Blue Cave fault plane, as also visible on the cliff outside the submerged entrance to the cave (Figure 3B). 


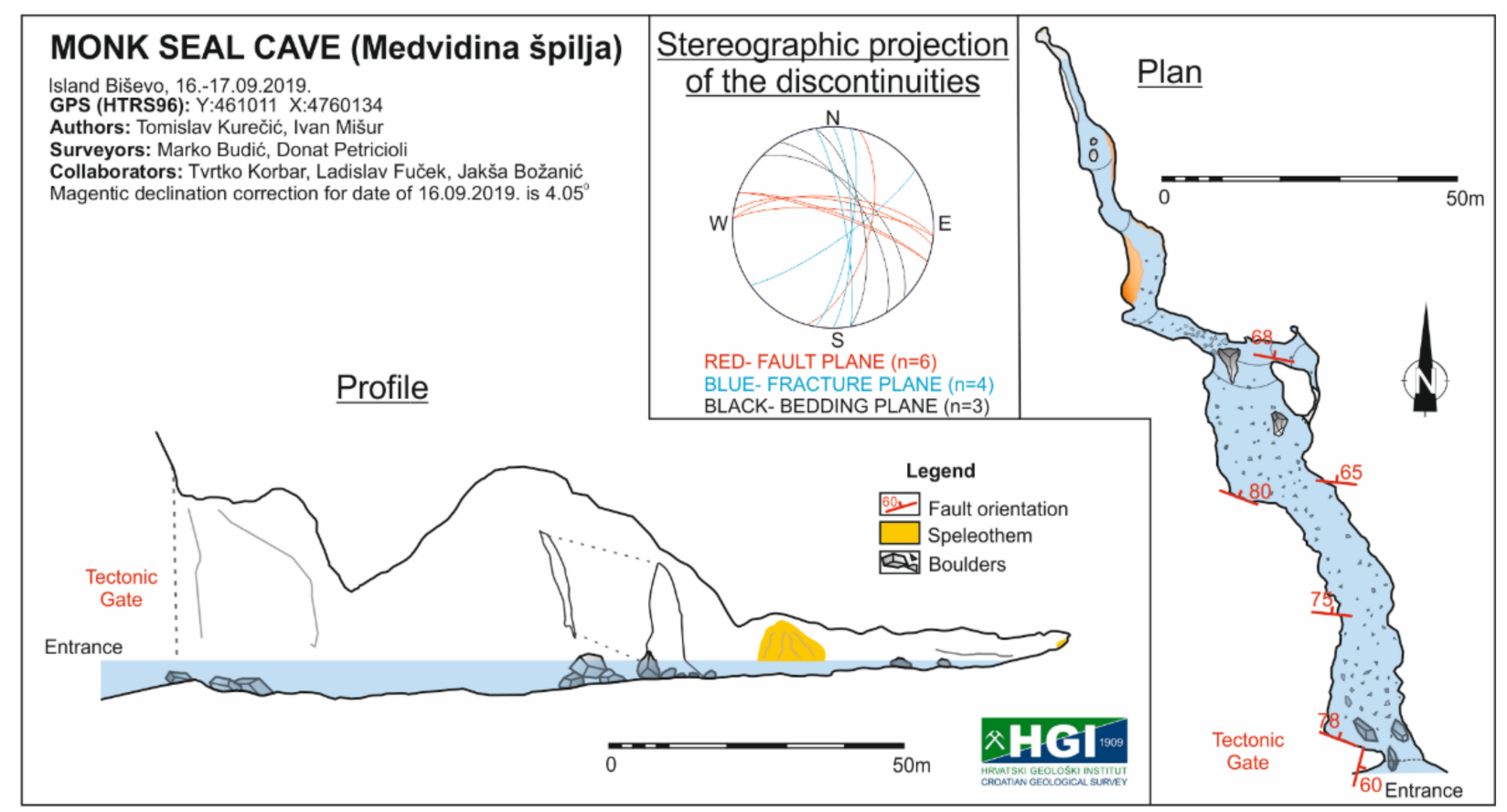

Figure 6. Plan and profile of the Monk Seal Cave (Medvidina špilja) (cave symbols according to [23,24]), with marked orientations of the bedding and fault planes. Stereographic projection (top centre) of all measured discontinuities on the surfaces and in the cave (lower-hemisphere projection).

The Blue Cave fault (Figures 2 and $3 \mathrm{~A}$ ) is the most prominent fault on the island, characterised by a left-lateral strike-slip shift of approximately $1 \mathrm{~km}$. The fault separates the MŠ formation to the east from the BI formation to the west (Figure 2), and the fault plane is visible from the main cave entrance (Figure 5A,B). Secondary (conjugated) fractures were also measured and are shown on the cave map (Figures 4 and 5C,E). Observed speleothems (mainly cave popcorn) were rare and poorly developed.

In the submerged parts of the cave, morphological features were not observed due to thick biological encrustations and marine biota. Only indistinct indications of tidal notches at a depth of $1 \mathrm{~m}$ below mean sea level at the main entrance were recognised. The bottom of the cave is partially covered with sediment, primarily white sand and rock boulders with a diameter up to $1.5 \mathrm{~m}$ (Figure 4).

\subsection{The Monk Seal Cave}

The Monk Seal Cave is $162 \mathrm{~m}$ long, with a maximum channel height of almost $30 \mathrm{~m}$. The general orientation of the cave is NNW-SSE. The lower part of the cave channel is submerged with a maximum depth at the entrance area of approximately $-4 \mathrm{~m}$ (Figure 6).

Rocks hosting the cave are highly fractured crystalline dolostones that belong to the Lower Cretaceous Barjak member (BK on Figure 2). Bedding around the cave (measured on the surface) generally dips steeply to the NE (Table 2). The bedding planes were not observed in the cave due to highly fractured wall surfaces and numerous fault planes. Many rock boulders were found on the bottom of the cave, and numerous discontinuities were observed in the host rock. Six prominent fault planes were measured and drawn on the cave map (Figure 6). Five of them had a similar WNW-ESE strike and a steep dip angle ranging from $65^{\circ}$ to $80^{\circ}$. The fault observed on the cave entrance belongs to the NNE-SSW striking Biševo fault system (105/60), while the spectacular fault plane of a conjugated dextral strike-slip fault (20/78) is visible from the cave (Tectonic Gate, Figures 6 and 7D). Few active speleothems (stalagmites, stalactites, small drapery, and rimstone pool) were found deeper in the cave (Figure 7E). 


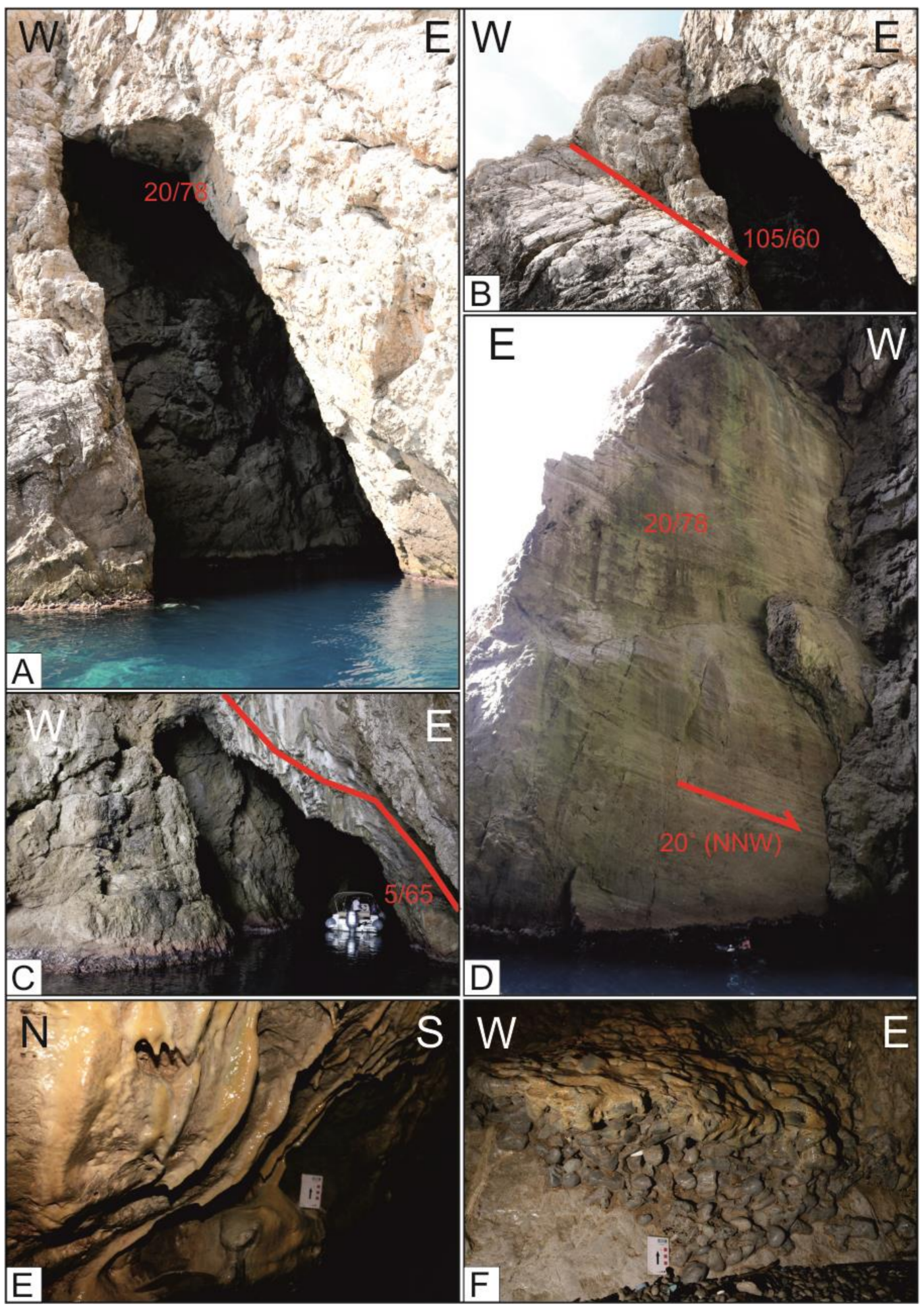

Figure 7. On the photographs of the Monk Seal Cave, structural measurements are marked. The red lines mark fault planes (dip direction/dip angle are marked in red numbers). (A) Entrance to the Monk Seal Cave. (B) Fault plane observed on the entrance to the cave. (C) Fault plane in the middle section of the cave, located at the ceiling. (D) WNW-ESE striking strike-slip fault plane at the entrance to the Monk Seal Cave (The Tectonic Gate), with marked slip direction (dextral movement). (E) Speleothems at the furthest section in the cave. (F) Paleo beach conglomerates at the northern tip of the Monk Seal Cave, located $0.5 \mathrm{~m}$ above a small pebbly beach. 
No speleothems were observed on the submerged part of the cave, the bottom of which is covered mainly with rock boulders and calcareous sand sediment. The rock boulders were mostly of decimetric dimensions; however, a few boulders of up to $5 \mathrm{~m}$ were also observed and drawn (Figure 6). At the northern tip of the cave is a small beach composed predominantly of dolomite pebbles (Figure 7F). One meter above the beach is approximately $50 \mathrm{~cm}$ thick paleo beach conglomerates composed of predominantly dolomite pebbles and semi-rounded cobbles cemented by calc-siltite. The top of the conglomerates is covered by thin speleothem crusts.

\section{Discussion}

Numerous fault planes observed and measured in both caves are also visible on the surface (Figure 2), implying a strong influence of the tectonic structure on the Blue and Monk Seal Cave pattern. Structural features recognised within caves correlate with the features observed on the surface (Tables 2 and 3).

The major Blue Cave fault, together with paired and conjugated faults and fractures, as well as bedding plane discontinuities (Figures 4 and 8), predisposed the host rock to weathering and influenced the position of the Blue Cave. Numerous discontinuities observed in the cave (Figures 4 and $5 \mathrm{C}, \mathrm{E}$ ) weakened the rock and made it prone to collapsing and further weathering, which facilitated the widening of the cave passage.

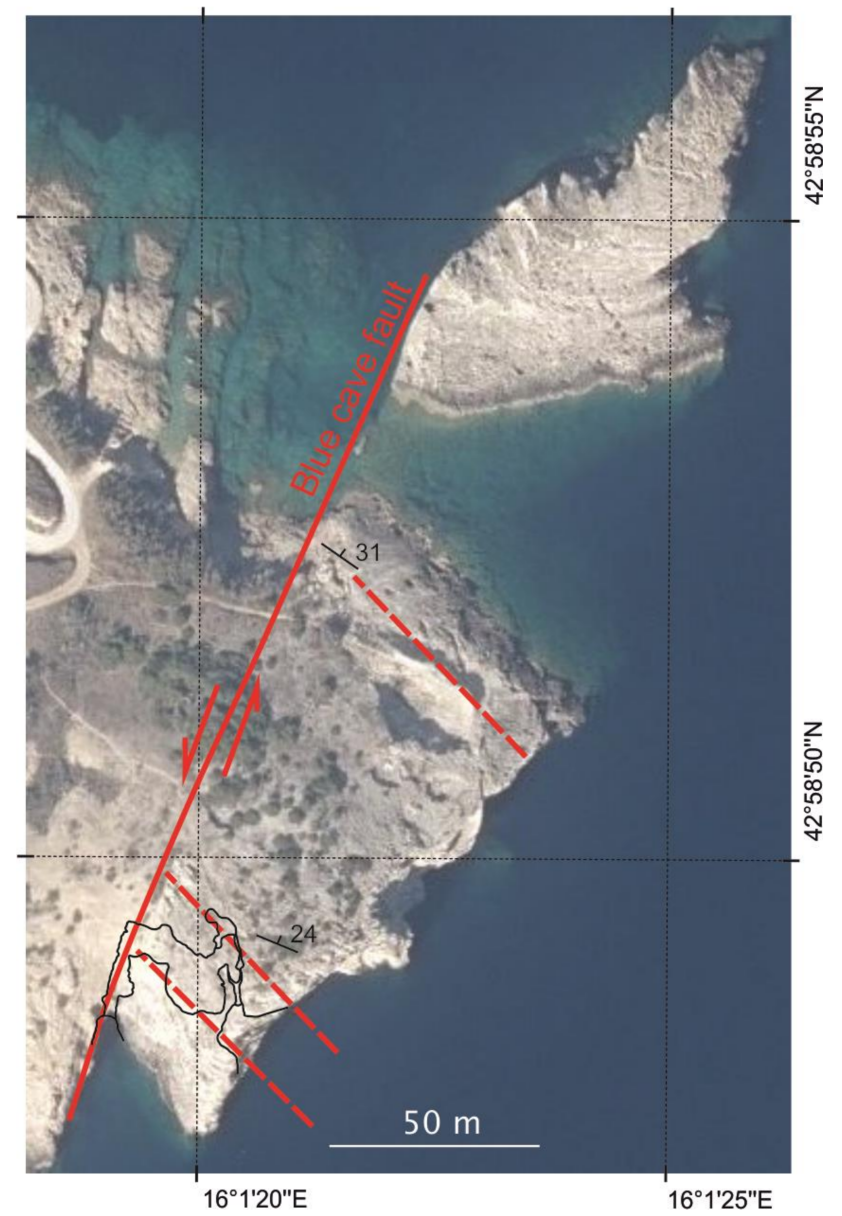

Figure 8. Satellite image of the Blue Cave area, with overlapped plan of the cave (black outline). The red line marks a position of the Blue Cave fault observed on the surface. Dashed red lines mark the position of the fracture system observed in the cave and on the surface; the black marks indicate the dip direction and dip angle (number) of the bedding (same as in Figure 2). The satellite image was acquired from: http:/ / www.arkod.hr/, accessed on 4 July 2021. 
The Monk Seal Cave is predominantly of a linear layout with a general direction of SE-NW (Figures 6 and 9A,B). The orientation of the two most prominent fault planes in the cave, one at the entrance to the cave (Tectonic gate) and the fault plane in the central part of the cave, are similar. Both planes are steeply inclined to NNE and of dextral (right-lateral) strike-slip shift. This feature is typical for an extensive strike-slip fault system. In the vicinity of the cave is a major sinistral (left-lateral) strike-slip fault (Biskup fault) which is also known as the Blue Cave fault, part of the larger zone of the Biševo fault system (Figure 2) that is characterised by NNE-SSW strike. The location and orientation of the fault planes from the Monk Seal Cave are probably related to the major Biševo fault zone and related Biskup fault. On a rose diagram (Figure $9 \mathrm{~B}$ ), the general cave direction is similar to the channel direction trend of NW-SE and oriented approximately $30^{\circ}$ counterclockwise to a Biskup fault. The most prominent fault planes in the cave have directions almost perpendicular to the Biskup fault zone (approximately $80^{\circ}$, see Figure 9 ) and are antithetic in reference to the Biskup strike-slip fault zone.

According to the ideal Riedel shear structure proposed by few authors [25,26], structures measured in the Monk Seal Cave correlate almost ideally to this scenario (Figure 9). The fault planes measured in the cave almost perfectly match the antithetic Riedel shear system (' $\mathrm{R}$ in Figure 9). The fault plane visible at the entrance to the cave (Figure 7B) and in the satellite image (Figure 9A), with an orientation of 105/60, is likely part of the synthetic Riedel shear system ( $R$ in Figure 9). In this scenario, the Monk Seal Cave is oriented as a tension gap in the structure ( $\mathrm{T}$ in Figure $9 \mathrm{C}$ ), parallel to the $\sigma_{1}$ (vector of maximal stress) and angled $30^{\circ}$ to $40^{\circ}$ to a principal displacement zone (in our scenario, the Biševo fault system) (Figure 9C). This model suggests that the Monk Seal Cave was generated as an extension structure in a Riedel shear system of the Biševo strike-slip fault zone. This theory is supported by the boulders that fill the bottom of the cave (Figure 6), which are interpreted as collapsed boulders, indicating lateral widening and collapsing of the ceiling parts of the cave. The Monk Seal Cave was likely initiated in an extensional strike-slip tectonic regime along the major left-lateral Biskup fault and the conjugated Riedel shear set of secondary strike-slip faults (Figures 6 and 9).

In the Blue Cave, small speleothems in the initial growth phase are observed only on the dry parts of the cave. Submerged parts of the cave walls are covered by thick biogenic carbonate encrustations and living marine biota. Such extensive marine biogenic overgrowths document the lack of freshwater influence and can be considered as a proxy record of entirely marine conditions within submerged parts of caves [27]. The lack of submerged speleothems could indicate the nonexistence of cave channels of the Blue Cave during the former lower sea stands. However, small forms of recent speleothems and the lack of old speleothems could be related to numerous variables.

A slightly larger diversity in speleothems observed within the Monk Seal Cave (Figure 7E,F) suggests somewhat favourable conditions for speleothem growth, such as a more stable freshwater supply in a relatively protected environment. Such discrepancies of speleothem occurrence and growth rates within spatiotemporally related caves are common along the Croatian Adriatic Coast, connected mainly to specific local conditions in the transition zone between the temperate Mediterranean and the periglacial parts of Europe during the last $220 \mathrm{ky}$ [27]. Although the Late Holocene biogenic constructions suggest stable tectonic conditions during the last 1500 years [21], paleo beach conglomerates above the small recent pebbly beach in the Monk Seal Cave could suggest uplifting of the island. However, the conglomerates could have been formed during MIS 5.5 [28] when the sea level was a few meters higher than today. Unfortunately, the fine carbonate siltite in the cement/matrix of the conglomerates was not analysed since the cave is under protection. 


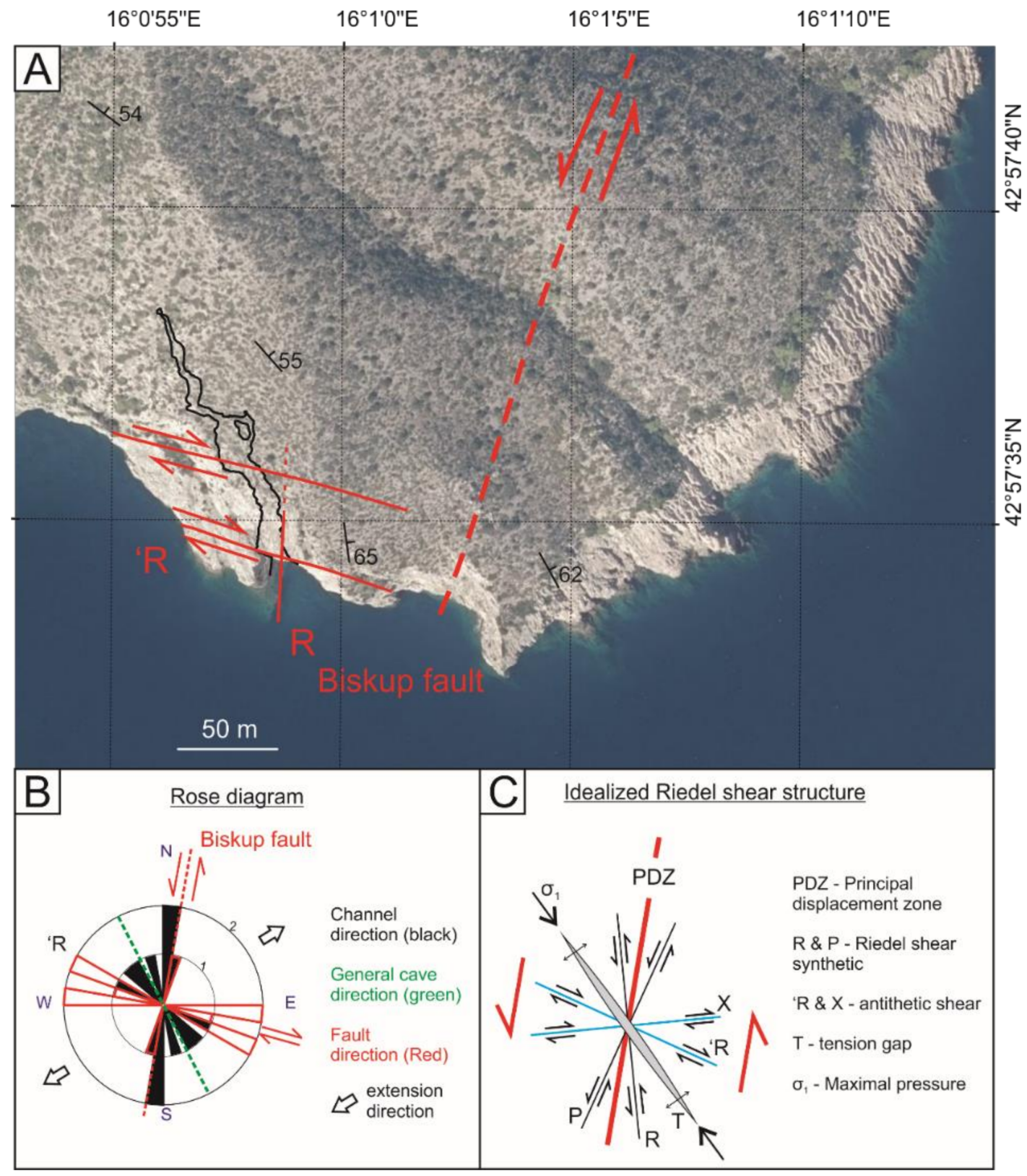

Figure 9. (A) Satellite image of the Monk Seal Cave area, with overlapped plan of the cave (black outline). The red lines mark the faults observed on the surface concordant with those measured in the cave (Riedel shear system, R-synthetic, 'R-antithetic). The black mark indicates strike, dip direction, and dip angle (number) of the bedding (same as in Figure 2). The satellite image was acquired from http:/ / www.arkod.hr/, accessed on 4 July 2021. (B) Rose diagram, where black triangles represent the direction of the channels in the cave, and red transparent triangles are the direction of the fault planes inside of the cave. In the diagram, the Biskup fault is also marked with a red dashed line. The green dashed line is the general direction of the cave. (C) Schematic idealised Riedel shear structure system according to $[25,26]$.

Exposure to the open sea in the present-day tidal zone of the coastline (Figures 1 and 2) suggests an abrasion influence of the strong storm waves on fragmented host rocks in both caves. Although sea caves have been developed worldwide on comparably steep coasts and below coastal cliffs of various lithology on recent or former coastlines (e.g. [29,30]), the abrasion forming model of typical sea caves cannot be considered the only model on the coastline of Biševo. Therefore, predominantly tectonically defined fragments of the host rock were subsequently collapsed and eroded, and the cave is still forming through abrasion and corrosion processes. 
Along the Croatian coast and islands, numerous submerged caves that do not fit into sea cave or a flank margin cave development model are common and considered unique [31]. However, there are also occurrences of flank margin caves [32] connected to the island freshwater or brackish water lenses. In the Adriatic area, numerous freshwater and brackish groundwater lenses have been documented on islands [33], even on small Dinaric karst islands [34]. However, such freshwater or brackish groundwater lenses have not been documented on the island of Biševo [33]. Therefore, the flank margin cave model [35] and the typical Carbonate Island Karst Model [36] can probably be excluded from interpretation of the speleogenesis of the Monk Seal and Blue Cave on Biševo. To conclude, the described structural features and pronounced breakdown processes are a predominant process responsible for increasing the overall volume of mentioned caves.

\section{Conclusions}

Biševo Island is dissected by a major strike-slip fault system, oriented NNE-SSW, which probably produced the classical Riedel shear structures of secondary strike-slip faults and fractures.

The two most famous caves on the island, the Blue Cave and the Monk Seal Cave, were formed due to tectonic weakening of the bedrock carbonates along the tectonic discontinuities that, along with the bedding planes discontinuities, formed the rock fragments. The fragmented host rock was subsequently exposed to gravitational collapses, intensive abrasion, erosion, and corrosion.

Development of the Blue Cave was predominantly related to the homonymous fault, one of the main faults in the Biševo fault system. Conjugate faults and fractures indicate an influence of extensional tectonic factors on the genesis of the most prominent chamber in the Blue Cave.

Similarly, the Monk Seal Cave was formed in conjunction with the two fault systems, one belonging to the sinistral Biševo fault system and its conjugate dextral faults. The Monk Seal Cave was developed probably along an extensional zone developed in the tension zone of the Riedel shear system related to Biševo Fault zone.

Lack of larger speleothems could have resulted from the younger age of the caves (Late Pleistocene to Holocene) and the impact of southern waves in the lower parts of the caves during the high sea levels (MIS 5.5 and/or MIS 1 i.e., the latest Holocene).

Distinct tectonic influence in generating and directing the orientation of the cave channels was noticed, whereas wave abrasion and sea erosion shaped channel surfaces, since both caves are under the direct influence of the strong southern waves. Thus, the structural features control the geometry of the two caves, whereas their genesis seems to have mainly been due to the mechanical removal of more fractured sectors of the host rocks. Dissolution played only a minor role, as also testified by the absence of sea-level notches.

Author Contributions: Conceptualisation, I.M. and T.K. (Tvrtko Korbar); methodology, I.M., M.B., T.K. (Tomislav Kurečić) and T.K. (Tvrtko Korbar); validation, I.M., M.B., T.K. (Tvrtko Korbar) and T.K. (Tomislav Kurečić); investigation, I.M., M.B., T.K. (Tomislav Kurečić) and T.K. (Tvrtko Korbar); resources, Croatian Geological Survey; writing—original draft preparation, I.M.; writing—review and editing, I.M., M.B., T.K. (Tomislav Kurečić) and T.K. (Tvrtko Korbar); funding acquisition, T.K. (Tvrtko Korbar). All authors have read and agreed to the published version of the manuscript.

Funding: This research was funded by Operational Programme Competitiveness and Cohesion 2014-2020 no. KK.06.1.2.02.0041 “Visitor Centre Modra špilja-Biševo”.

Acknowledgments: We gratefully thank colleagues Joško Božanić, Jakša Božanić, Pino Vojković, Branko Jalžić, Vedran Jalžić, Donat Petricioli, and Ladislav Fuček. We would especially like to thank the public institution "Sea and Karst" (Split) for the engagement of the Croatian Geological Survey within the Operational Programme Competitiveness and Cohesion 2014-2020 no. KK.06.1.2.02.0041, as well as the Komiža Nautical Centre (Town of Komiža) for logistic support.

Conflicts of Interest: The authors declare no conflict of interest. 


\section{References}

1. Korbar, T.; Božanić, J. Geoparks-Sustainable development of world-class geotourism based on natural resources: An example for Central Adriatic Islands (Vis archipelago, Croatia). In Proceedings of the Mediterranean Island Conference, Vis, Croatia, 21-24 September 2016; Kaliterna Lipovčan, L., Medić, R., Ramljak, O., Eds.; Institute of Social Science Ivo Pilar: Zagreb, Croatia, 2016; pp. 61-62.

2. Božanić, J. U Kamenu Svjetlo—Modra Špilja na Otoku Biševu; Ars Halieutica: Komiža, Croatia, 2016; p. 105.

3. Korbar, T.; Belak, M.; Fuček, L.; Husinec, A.; Oštrić, N.; Palenik, D.; Vlahović, I. Basic Geological Map of the Republic of Croatia, Scale 1:50.000-Sheet Vis 3 and Biševo 1, 571/3 i 621/1; Croatian Geological Survey: Zagreb, Croatia, 2012; ISBN 978-953-6907-27-4.

4. Filipčić, A. Klimatska Regionalizacija Hrvatske Po W. Köppenu Za Standardno Razdoblje 1961-1990. U Odnosu Na Razdoblje 1931-1960 [Climatic Regionalization of Croatia According to W. Köppen for the Standard Period 1961-1990 in Relation to the Period 1931-1960-In Croatian, with English Summary]. Acta Geogr. Croat. 1998, 34, 1-15.

5. Bonacci, O.; Patekar, M.; Pola, M.; Roje-Bonacci, T. Analyses of Climate Variations at Four Meteorological Stations on Remote Islands in the Croatian Part of the Adriatic Sea. Atmosphere 2020, 11, 1044. [CrossRef]

6. Channell, J.E.T.; D'Argenio, B.; Horvath, F. Adria, the African promontory, in Mesozoic Mediterranean palaeogeography. Earth-Sci. Rev. 1979, 15, 213-292. [CrossRef]

7. Koch, G.; Belak, M. Evaporitic—carbonate deposits of Komiža diapiric structure (Island of Vis, Croatia): Their palynostratigraphy and sedimentological features. In Proceedings of the 22nd IAS Meeting of Sedimentology, Opatija, Croatia, 17-19 September 2002; Croatian Geological Survey: Zagreb, Croatia, 2002; pp. 17-19.

8. Schmid, S.M.; Bernoulli, D.; Fügenschuh, B.; Matenco, L.; Schefer, S.; Schuster, R.; Tischler, M.; Ustaszewski, K. The AlpsCarpathians-Dinarides connection: A compilation of tectonic units. Swiss J. Geosci. 2008, 101, 139-183. [CrossRef]

9. De Min, A.; Jourdan, F.; Marzoli, A.; Renne, P.R.; Juračić, M. The tholeiitic Magmatism of Jabuka, Vis and Brusnik Islands: A Carnian magmatism in the Adria Plate. Rend. Online Soc. Geol. Ital. 2009, 9, 85-87.

10. Vlahović, I.; Tišljar, J.; Velić, I.; Matičec, D. Evolution of the Adriatic Carbonate Platform: Palaeogeography, main events and depositional dynamics. Palaeogeogr. Palaeoclimatol. Palaeoecol. 2005, 220, 333-360. [CrossRef]

11. Korbar, T. Orogenic evolution of the External Dinarides in the NE Adriatic region: A model constrained by tectonostratigraphy of Upper Cretaceous to Paleogene carbonates. Earth-Sci. Rev. 2009, 96, 296-312. [CrossRef]

12. Grandić, S.; Veseli, V.; Kolbah, S. Hydrocarbon potential of Dugi otok basin in offshore Croatia. Nafta 2002, 53, 215-224.

13. Korbar, T.; Fuček, L.; Premec Fućek, V.; Oštrić, N. Maastrichtian to Palaeocene and Eocene pelagic carbonates on the island of Svetac (central Adriatic, Croatia). Geol. Croat. 2020, 73, 95-106. [CrossRef]

14. Grandić, S.; Biancone, M.; Samaržija, J. Geophysical and stratigraphic evidence of the Triassic rift structuration in the Adriatic offshore area. Nafta 2001, 52, 383-396.

15. Geletti, R.; Del Ben, A.; Busetti, M.; Ramella, R.; Volpi, V. Gas seeps linked to salt structures in the Central Adriatic Sea. Basin Res. 2008, 20, 473-487. [CrossRef]

16. Battaglia, M.; Murray, M.H.; Serpelloni, E.; Bürgmann, R. The Adriatic region: An independent microplate within the AfricaEurasia collision zone. Geophys. Res. Lett. 2004, 31, L09605. [CrossRef]

17. Oldow, J.S.; Ferranti, L.; Lewis, D.S.; Campbell, J.K.; D’Argenio, B.; Catalano, R.; Pappone, G.; Carmignani, L.; Conti, P.; Aiken, C.L.V. Active fragmentation of Adria, the north African promontory, central Mediterranean region. Geology 2002, 30, 779-782. [CrossRef]

18. Herak, M.; Herak, D.; Markušić, S. Revision of the earthquake catalogue and seismicity in Croatia (1908-1992). Terra Nova 1996, 8, 86-96. [CrossRef]

19. Pikelj, K.; Hernitz-Kučenjak, M.; Aščić, Š.; Juračić, M. Surface sediment around the Jabuka Islet and the Jabuka Shoal: Evidence of Miocene tectonics in the Central Adriatic Sea. Mar. Geol. 2015, 359, 120-133. [CrossRef]

20. Wacha, L.; Montanari, A.; Lomax, J.; Fiebig, M.; Lüthgens, C.; Korbar, T.; Koeberl, C. Last Glacial Maximum giant sand dunes on the island of Vis, Croatia. In 250 Million Years of Earth History in Central Italy: Celebrating 25 Years of the Geological Observatory of Coldigioco; Koeberl, C., Bice, D., Eds.; Geological Society of America: Boulder, CO, USA, 2019; pp. 459-470. [CrossRef]

21. Faivre, S.; Bakran-Petricioli, T.; Horvatinčićc, N.; Sironić, A. Distinct phases of relative sea level changes in the central Adriatic during the last 1500 years-Influence of climatic variations? Palaeogeogr. Palaeoclimatol. Palaeoecol. 2013, 369, 163-174. [CrossRef]

22. Häuselmann, P. UIS Mapping Grades. Int. J. Speleol. 2011, 40, 4-6.

23. UIS Working Group on Cave Survey and Mapping 1995: Cave Symbols: The Official UIS List. UIS. Available online: https: //www.carto.net/neumann/caving/cave-symbols/ (accessed on 10 September 2019).

24. Barišić, T. Speleološki nacrt—topografsko snimanje i simboli. In Speleologija; Rnjak, G., Ed.; PDS Velebit, HPS, HGSS, SD Velebit: Zagreb, Croatia, 2019; pp. 441-489.

25. Xu, S.; Ben-Zion, Y. Numerical and theoretical analyses of in-plane dynamic rupture on a frictional interface and off-fault yielding patterns at different scales. Geophys. J. Int. 2013, 193, 304-320. [CrossRef]

26. Davis, G.H.; Bump, A.P.; García, P.E.; Ahlgren, S.G. Conjugate Riedel deformation band shear zones. J. Struct. Geol. 1999, 22, 169-190. [CrossRef]

27. Surić, M.; Juračić, M. Late Pleistocene-Holocene environmental changes—records from submerged speleothems along the Eastern Adriatic coast (Croatia). Geol. Croat. 2010, 63, 155-169. [CrossRef] 
28. Benjamin, J.; Rovere, A.; Fontana, A.; Furlani, S.; Vacchi, M.; Inglis, R.H.; Galili, E.; Antonioli, F.; Sivan, D.; Miko, S.; et al. Late Quaternary sea-level changes and early human societies in the central and eastern Mediterranean Basin: An interdisciplinary review. Quat. Int. 2017, 449, 29-57. [CrossRef]

29. Dipova, N.; Sukran Okudan, E. Sea Caves, Flank Margin Caves and Tufa Caves Observed on Antalya Coastal Cliffs. J. Coast. Res. 2011, 382-386. [CrossRef]

30. Sjöberg, R. Coastal Caves Indicating Preglacial Morphology in Norway. Cave Sci. 1988, 15, 99-103.

31. Surić, M.; Lončarić, R.; Lončar, N. Submerged caves of Croatia: Distribution, classification and origin. Environ. Earth Sci. 2010, 61, 1473-1480. [CrossRef]

32. Otoničar, B.; Buzjak, N.; Mylroie, J.; Mylroie, J. Flank Margin Cave Development in Carbonate Talus Breccia Facies: An Example from Cres Island, Croat. Acta Carsologica 2010, 39. [CrossRef]

33. Terzić, J. Hidrogeologija Jadranskih Krških Otoka. Ph.D. Thesis, University of Zagreb, Faculty of Mining, Geology and Petroleum, Zagreb, Croatia, 2007.

34. Terzić, J.; Grgec, D.; Lukač Reberski, J.; Selak, A.; Boljat, I.; Filipović, M. Hydrogeological estimation of brackish groundwater lens on a small Dinaric karst island: Case study of Ilovik, Croatia. Catena 2021, 204. [CrossRef]

35. Mylroie, J.E.; Carew, J.L. The flank margin model for dissolution cave development in carbonate platforms. Earth Surf. Process. Landf. 1990, 15, 413-424. [CrossRef]

36. Mylroie, J.E.; Mylroie, J.R. Development of the Carbonate Island Karst Model. J. Cave Karst Stud. 2007, 69, 59-75. 